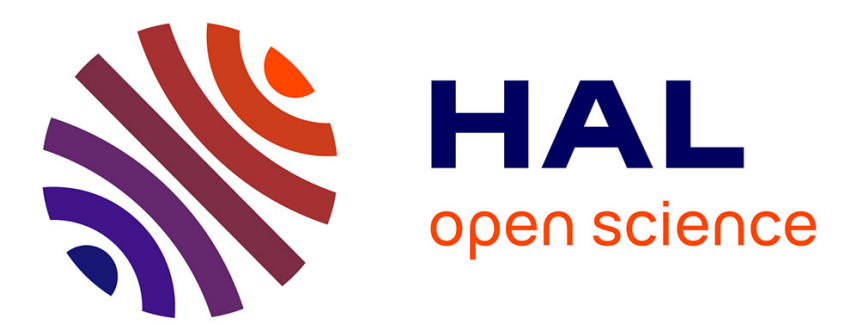

\title{
Just do it! How performing an action enhances remembering in transient global amnesia.
}

Mathieu Hainselin, Peggy Quinette, Aurelija Juskenaite, Béatrice Desgranges, Olivier Martinaud, Vincent de La Sayette, Didier Hannequin, Fausto Viader, Francis Eustache

\section{To cite this version:}

Mathieu Hainselin, Peggy Quinette, Aurelija Juskenaite, Béatrice Desgranges, Olivier Martinaud, et al.. Just do it! How performing an action enhances remembering in transient global amnesia.. Cortex, 2014, 50, pp.192-9. 10.1016/j.cortex.2013.10.007 . inserm-00931659

\section{HAL Id: inserm-00931659 https://www.hal.inserm.fr/inserm-00931659}

Submitted on 16 May 2014

HAL is a multi-disciplinary open access archive for the deposit and dissemination of scientific research documents, whether they are published or not. The documents may come from teaching and research institutions in France or abroad, or from public or private research centers.
L'archive ouverte pluridisciplinaire HAL, est destinée au dépôt et à la diffusion de documents scientifiques de niveau recherche, publiés ou non, émanant des établissements d'enseignement et de recherche français ou étrangers, des laboratoires publics ou privés. 
Provided for non-commercial research and education use. Not for reproduction, distribution or commercial use.

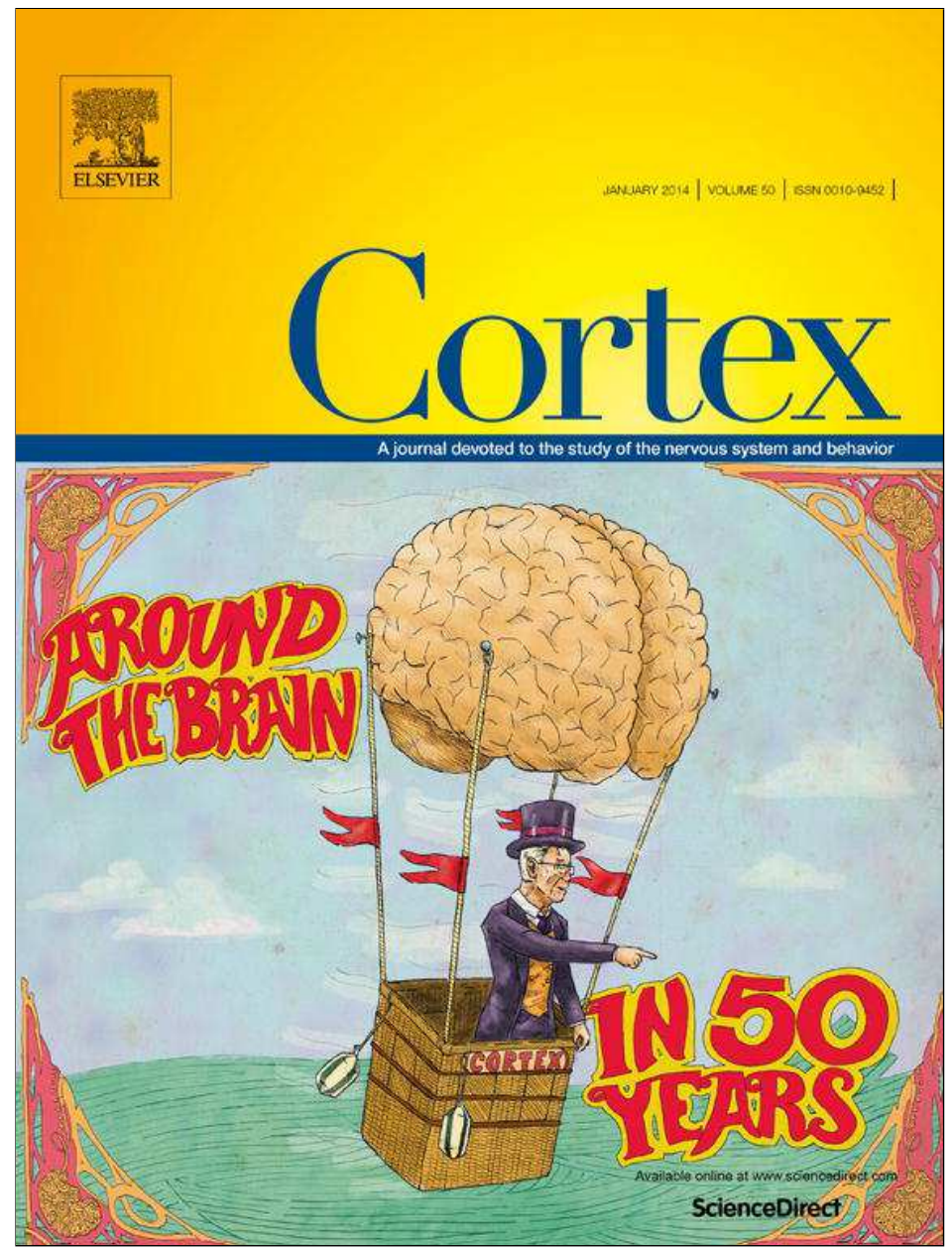

This article appeared in a journal published by Elsevier. The attached copy is furnished to the author for internal non-commercial research and education use, including for instruction at the authors institution and sharing with colleagues.

Other uses, including reproduction and distribution, or selling or licensing copies, or posting to personal, institutional or third party websites are prohibited.

In most cases authors are permitted to post their version of the article (e.g. in Word or Tex form) to their personal website or institutional repository. Authors requiring further information regarding Elsevier's archiving and manuscript policies are encouraged to visit:

http://www.elsevier.com/authorsrights 


\title{
Just do it! How performing an action enhances remembering in transient global amnesia
}

\author{
Mathieu Hainselin ${ }^{a, b, c, d}$, Peggy Quinette ${ }^{a, b, c, d}$, Aurelija Juskenaite ${ }^{a, b, c, d}$, \\ Béatrice Desgranges ${ }^{a, b, c, d}$, Olivier Martinaud ${ }^{f}$, Vincent de La Sayette ${ }^{a, b, c, e}$, \\ Didier Hannequin ${ }^{f, g}$, Fausto Viader ${ }^{a, b, c, e}$ and Francis Eustache ${ }^{a, b, c, d, *}$ \\ ${ }^{\mathrm{a}}$ Inserm, U1077, Caen, France \\ ${ }^{\mathrm{b}}$ Université de Caen Basse-Normandie, UMR-S1077, Caen, France \\ c Ecole Pratique des Hautes Etudes, UMR-S1077, Caen, France \\ ${ }^{\mathrm{d}} \mathrm{CHU}$ de Caen, U1077, Caen, France \\ ${ }^{\mathrm{e}} \mathrm{CHU}$ de Caen, Service de Neurologie, Caen, France \\ ${ }^{\mathrm{f}} \mathrm{CHU}$ de Rouen, Rouen, France \\ ${ }^{\mathrm{g}}$ Inserm, U1079, Rouen, France
}

\section{A R T I C L E I N F O}

Article history:

Received 5 March 2013

Reviewed 5 May 2013

Revised 2 August 2013

Accepted 21 October 2013

Action editor Georg Goldenberg

Published online 30 October 2013

\section{Keywords:}

Transient global amnesia

Enactment effect

Self-performed task

Binding

Memory for action

\begin{abstract}
A B S T R A C T
Transient global amnesia (TGA) is a clinical syndrome characterized by the sudden onset of a massive episodic memory deficit that spares other cognitive functions. As such, it provides a unique human amnesia model for testing the enactment effect (i.e., better memory for performed actions than for verbally encoded sentences). Our main aim was to test whether the enactment effect is preserved in TGA patients, both to have a better understanding and to test the robustness of this effect in a massive amnesia.

Object-action pairs were encoded under four conditions: verbal, experimenterperformed, and two enacted conditions (self-performed and self-performed with choice). We tested object-action pair retrieval using cued recall (CR) and recognition tasks, and source memory using a free recall task. We also assessed binding, executive functions, short-term memory, episodic memory, anxiety and mood. We run correlations to control for their putative effects on memory for action. Data were collected from 24 patients, 16 of whom were examined during the acute phase and eight the day-after, as well as from 18 healthy controls.

The memory performances of the patients in the acute phase improved for both i) the CR score, between the verbal, experimenter-performed and self-performed with choice conditions, and ii) the total recognition score, between the verbal condition and the two enacted conditions. Correlations were found between self-performed task (SPT) enhancement and both the binding and anxiety.
\end{abstract}

\footnotetext{
* Corresponding author. Inserm - EPHE - Université de Caen Basse-Normandie, Unité de recherche U1077, "Neuropsychologie et neuroanatomie fonctionnelle de la mémoire humaine", CHU, Avenue de la Côte de Nacre, 14033 Caen Cedex 09, France.

E-mail addresses: neuropsycho@chu-caen.fr, francis.eustache@inserm.fr (F. Eustache). 0010-9452/\$ - see front matter ๑ 2013 Elsevier Ltd. All rights reserved. 
In spite of their severely impaired episodic memory, patients with TGA benefit from the enactment effect. These results are discussed in relation to the role of motor components and episodic integration in memory for actions. We suggest that enactment effect can be used in clinical practice and rehabilitation, possible even for patients with a massive memory impairment.

(c) 2013 Elsevier Ltd. All rights reserved.

\section{Introduction}

Transient global amnesia (TGA) is a neurological syndrome that occurs in middle age and lasts up to $24 \mathrm{~h}$. Its aetiology remains elusive, despite recent evidence of transient focal abnormalities in the CA1 hippocampal region (Bartsch et al, 2008). This amnesia is characterized by the sudden onset of massive anterograde amnesia with no attendant neurological or cognitive impairments (Quinette, Guillery-Girard, Dayan et al., 2006). During the acute phase, patients also display increased anxiety and a deterioration in mood, which have a deleterious impact on episodic memory functioning (Noël et al., 2008).

Despite the massiveness of the episodic memory deficit, which is present whatever the types of materials that have to be memorized and whatever the encoding and retrieval conditions, TGA patients have been shown to be capable of acquiring new skills in procedural memory (Eustache et al., 1997), the perceptual representation system (Kazui \& Tanabe, 1995), and semantic memory (Beauregard, Weiner, Gold, \& Chertkow, 1997; Guillery et al., 2001), using priming effects. No study, however, has ever investigated whether TGA patients can improve their episodic memory performance during the amnesic episode.

In the past three decades, many studies have focused on memory for actions (for a review, see Engelkamp, 1998; Nilsson, 2000), a particular form of episodic memory (Tulving, 2002; Zimmer et al., 2001). Most of them focused on enactment effect, an improvement of recall and recognition scores for action phrases (e.g., "put on a glove", "move the pen to the right") when participants perform the actions (subjectperformed task or SPT) during encoding compared with classic condition under which participants merely listen to or read the phrases (verbal task or VT).

Of the few studies that have explored this memory for actions in pathological conditions (for review, see Hainselin, Quinette, \& Eustache, 2013), the majority have demonstrated the robustness of the enactment effect in children with autistic spectrum disorders, Parkinson's disease and frontal lobe syndrome and Korsakoff's syndrome while only a little benefit was observed in schizophrenia and sometimes in Alzheimer's disease, and in rats (Thompson, 1959). However, a patient with developmental amnesia (Gardiner, Brandt, Vargha-Khadem, Baddeley, \& Mishkin, 2006) showed no enactment benefit, suggesting other functions than episodic memory might contribute to this effect.

Although the enactment effect has frequently been studied since the 1980's, there is still no consensus on how it enhances memory (for review, see Madan \& Singhal, 2012), including if it is supported by episodic memory. There are two main schools of thought: according to Engelkamp (2001), participants first have to plan the action, involving motor and visual information. This multimodal theory is supported by the advantage of SPTs over experimenter-performed tasks (EPTs), when healthy participants simply observe somebody else performing the action. The planning component does, however, seem to be essential, but needs to be more extensively studied, for example by letting participants choose which actions to perform with the different objects. According to Kormi-Nouri and Nilsson (2001), enactment enhances episodic integration, binding the action verbs and object nouns together. This "glue" theory has mostly been studied by comparing wellintegrated ("put the money in the wallet") and poorly integrated ("put the money in the napkin") actions (Mangels \& Heinberg, 2006). Although this second hypothesis is a very important topic of discussion, binding itself had never been assessed with a specific task.

Thus, the main aim of our study was to assess whether the enactment effect is sufficiently robust for it to be observed during a massive amnesia episode such as TGA. Our second objective was to gain a better understanding of how enactment enhances memory by investigating the functions that sustain the enactment effect on patients. To this end, we chose to assess binding with a specific task to test the "glue" theory. Inhibition and shifting (as patients have to perform different actions and shift from one to the other), short-term

Table 1 - Clinical and demographic characteristics of individuals with TGA and controls.

\begin{tabular}{|c|c|c|c|}
\hline & $\begin{array}{c}\text { Acute } \\
\text { TGA }(n=16)\end{array}$ & $\begin{array}{c}\text { Day-after } \\
\text { TGA }(n=8)\end{array}$ & $\begin{array}{l}\text { Healthy } \\
\text { controls } \\
(n=18)\end{array}$ \\
\hline Sex: women/men & $13 / 3$ & $4 / 4$ & $13 / 5$ \\
\hline $\begin{array}{l}\text { Age in years: } \\
\text { mean (SD) }\end{array}$ & $60.56(5.42)$ & $68.3^{\mathrm{a}, \mathrm{b}}(6.45)$ & $61.00(6.48)$ \\
\hline $\begin{array}{l}\text { Level of } \\
\text { education } \\
\text { in years: } \\
\text { mean (SD) }\end{array}$ & $11.56(2.99)$ & $10.00(3.51)$ & $10.56(2.20)$ \\
\hline $\begin{array}{l}\text { Duration of TGA } \\
\text { in hours: } \\
\text { mean (SD) }\end{array}$ & $4.96(3.37)$ & $3.81(2.5)$ & / \\
\hline $\begin{array}{l}\text { No. recurrent } \\
\text { patients }\end{array}$ & $\begin{array}{l}2 \text { (Second } \\
\text { episode) }\end{array}$ & $\begin{array}{l}1 \text { (Second } \\
\text { episode) }\end{array}$ & / \\
\hline
\end{tabular}

A comparison of the three groups showed an effect of Group on age, $F(2,39)=5.05, p<.05$. A post hoc Tukey test showed this was due to the presence of older patients in the day-after group compared with the acute and healthy control groups.

a Significant difference from healthy control group.

significant difference from acute TGA group. 
Table 2 - Example of an entire list of 48 object-action sentences used for the enactment effect task.

\begin{tabular}{|c|c|}
\hline French & English translation \\
\hline $\begin{array}{l}\text { Déplacer le déodorant derrière } \\
\text { l'ordinateur }\end{array}$ & $\begin{array}{l}\text { Move the deodorant behind } \\
\text { the computer }\end{array}$ \\
\hline Déplacer l'allumette à droite & Move the match to the right \\
\hline $\begin{array}{l}\text { Prendre le marteau entre le } \\
\text { pouce et l'index }\end{array}$ & $\begin{array}{l}\text { Grab the hammer with the } \\
\text { thumb and forefinger }\end{array}$ \\
\hline $\begin{array}{l}\text { Serrer la boucle d'oreille dans la } \\
\text { main }\end{array}$ & $\begin{array}{l}\text { Tighten the earring in the } \\
\text { hand }\end{array}$ \\
\hline $\begin{array}{l}\text { Une action de votre choix avec } \\
\text { l'élastique }\end{array}$ & $\begin{array}{l}\text { An action you choose with } \\
\text { the elastic }\end{array}$ \\
\hline Frotter le taille-crayon & Rub the pencil sharpener \\
\hline $\begin{array}{l}\text { Une action de votre choix avec } \\
\text { le niveau }\end{array}$ & $\begin{array}{l}\text { An action you choose with } \\
\text { the spirit level }\end{array}$ \\
\hline Caresser la balle de ping-pong & Caress the ping-pong ball \\
\hline Essuyer le bonbon & Wipe the candy \\
\hline Soupeser le thermomètre & Heft the thermometer \\
\hline Tordre le filtre à café & Twist the coffee filter \\
\hline $\begin{array}{l}\text { Appuyer sur le couteau avec } \\
\text { l'index }\end{array}$ & $\begin{array}{l}\text { Press the knife with the } \\
\text { forefinger }\end{array}$ \\
\hline Lancer le trombone en l'air & Toss the paperclip \\
\hline $\begin{array}{l}\text { Une action de votre choix avec } \\
\text { les ciseaux }\end{array}$ & $\begin{array}{l}\text { An action you choose with } \\
\text { the scissors }\end{array}$ \\
\hline $\begin{array}{l}\text { Tourner le mètre dans le sens } \\
\text { antihoraire }\end{array}$ & $\begin{array}{l}\text { Turn the ruler } \\
\text { counterclockwise }\end{array}$ \\
\hline $\begin{array}{l}\text { Une action de votre choix avec } \\
\text { la cassette }\end{array}$ & $\begin{array}{l}\text { An action you choose with } \\
\text { the tape }\end{array}$ \\
\hline Pincer la clé & Pinch the key \\
\hline Retourner la pince & Upturn the pliers \\
\hline $\begin{array}{l}\text { Une action de votre choix avec } \\
\text { l'éponge }\end{array}$ & $\begin{array}{l}\text { An action you choose with } \\
\text { the sponge }\end{array}$ \\
\hline Ecraser la gomme avec la main & $\begin{array}{l}\text { Crush the eraser with the } \\
\text { hand }\end{array}$ \\
\hline $\begin{array}{l}\text { Une action de votre choix avec } \\
\text { la pile }\end{array}$ & $\begin{array}{l}\text { An action you choose with } \\
\text { the battery }\end{array}$ \\
\hline $\begin{array}{l}\text { Taper sur le bureau avec le } \\
\text { crayon de couleur }\end{array}$ & $\begin{array}{l}\text { Thump the desk with the } \\
\text { coloured pencil }\end{array}$ \\
\hline Plier la carte & Bend the card \\
\hline $\begin{array}{l}\text { Passer la cuillère d'une main à } \\
\text { l'autre }\end{array}$ & $\begin{array}{l}\text { Pass the spoon from one } \\
\text { hand to the other }\end{array}$ \\
\hline Souffler sur le tube de dentifrice & Blow on the toothpaste tube \\
\hline $\begin{array}{l}\text { Une action de votre choix avec } \\
\text { le gant }\end{array}$ & $\begin{array}{l}\text { An action you choose with } \\
\text { the glove }\end{array}$ \\
\hline $\begin{array}{l}\text { Une action de votre choix avec } \\
\text { le bouton }\end{array}$ & $\begin{array}{l}\text { An action you choose with } \\
\text { the button }\end{array}$ \\
\hline Déplacer les lunettes à gauche & Move the glasses to the left \\
\hline Jeter la craie par terre & Throw the chalk on the floor \\
\hline Mettre le bonnet dans la main & Put the bonnet in the hand \\
\hline $\begin{array}{l}\text { Une action de votre choix avec } \\
\text { la brosse à dents }\end{array}$ & $\begin{array}{l}\text { An action you choose with } \\
\text { the toothbrush }\end{array}$ \\
\hline Poser le peigne par terre & Put the comb on the floor \\
\hline Poser le coton tige sur la chaise & Put the swab on the chair \\
\hline Palper la lime à ongles & Palpate the nail file \\
\hline $\begin{array}{l}\text { Donner le rasoir à la personne } \\
\text { en face }\end{array}$ & $\begin{array}{l}\text { Give the razor to the person } \\
\text { in front of you }\end{array}$ \\
\hline Ramener le savon vers soi & $\begin{array}{l}\text { Take the soap back to } \\
\text { oneself }\end{array}$ \\
\hline Tapoter le collier & Tap the necklace \\
\hline Visser avec la bague & Screw with the ring \\
\hline $\begin{array}{l}\text { Une action de votre choix avec } \\
\text { l'agrafeuse }\end{array}$ & $\begin{array}{l}\text { An action you choose with } \\
\text { the stapler }\end{array}$ \\
\hline Secouer le cahier & Shake the notebook \\
\hline Gratter la louche & Scratch the ladle \\
\hline Cacher le tournevis & Hide the screwdriver \\
\hline
\end{tabular}

Table 2 - (continued)

\begin{tabular}{ll} 
French & \multicolumn{1}{c}{ English translation } \\
\hline Pousser le téléphone & Push the phone \\
Une action de votre choix avec & An action you choose with \\
la bougie & the candle \\
Faire rouler la fourchette & Make the fork roll \\
Tourner le pinceau dans le sens & Turn the paintbrush \\
horaire & clockwise \\
Une action de votre choix avec & An action you choose with \\
le bracelet & the bracelet \\
Poser le gobelet sur la main & Put the cup on your hand \\
\hline
\end{tabular}

memory and episodic memory itself, thought to influence enactment effect, were also assessed. Given the impact of patients' emotional state on memory, especially during TGA, we also wondered whether anxiety and mood might diminish the enactment effect.

\section{Methods}

\subsection{Participants}

Twenty-four TGA patients admitted to the emergency departments of Caen and Rouen University Hospitals between June 2010 and March 2012 were included in the study. Of these patients, 16 were in the acute phase (acute) and eight in the post-acute phase (day-after). Descriptive data are reported in Table 1. Eight of them (six acute and two dayafter) were drawn from the cohort of a previously published study of awareness of memory failure (Hainselin et al., 2012). The control group consisted of 18 healthy individuals. All participants gave their written informed consent to the study, which was approved by the local ethics committee.

All patients met the standard clinical criteria for the diagnosis of TGA published by Hodges and Warlow (1990). The 16 acute patients were examined during the TGA episode itself, and the eight day-after patients were assessed at the end of the episode. For all patients, a follow-up examination was carried out two months later (mean interval $=69.59$ days, $\mathrm{SD}=9.13$ ). By that stage, none of the patients exhibited any memory impairment. Finally, at the first test session, patients and controls underwent an assessment of two potentially confounding factors, namely visuoconstructive abilities (Signoret et al., 1989) and apraxia (Peigneux \& Van der Linden, 2000). No impairment was found (data not shown). The acute patients were matched with healthy controls for sex, age and level of education.

\subsection{Memory for action task}

Participants incidentally encoded 48 object-action sentences (see Table 2 for an example of a complete list of items) under four conditions: VT, EPT, SPT and self-performed task with choice (SPTc; see Fig. 1 for the general design and task details).

Immediate retrieval was assessed for each object-action sentence via cued recall (CR), recognition and source 
memory (free recall) tasks. We collected and analysed the CR and total recall (correct responses on $\mathrm{CR}+$ recognition) scores. For correctly recalled or recognized items, we collected and analysed $\mathrm{R} / \mathrm{K} / \mathrm{G}$ and source memory scores to assess the participants' subjective experience.

\subsection{Complementary cognitive assessment}

The neuropsychological protocol was designed to assess binding, executive functions, short-term memory and episodic memory. Due to the specific nature of TGA, the cognitive assessment was modular and could be applied to the patients in the form of short sequences interleaved with medical examinations.

Binding, a process thought to take place in the episodic buffer, was assessed using a verbal and visuospatial association task (for complete description, see Quinette, Guillery-Girard, Noël et al., 2006; Quinette et al., 2013) (see Supplementary material).

Episodic memory was assessed with the Encoding Storage - Retrieval (ESR) test, to which we added a Remember/Know/Guess (R/K/G; Gardiner, Ramponi, \& Richardson-Klavehn, 1998) paradigm (the R, K and G scores are expressed as percentages in the statistical analysis). This has been used and described in previous studies of TGA (Hainselin et al., 2011; Quinette, Guillery-Girard, Noël et al., 2006).

We investigated two executive functions, namely inhibition and shifting, using the Stroop test and the Trail Making Test, respectively (Godefroy, 2008). Forward digit and forward visuospatial span tasks (Wechsler, 1991) were used to probe short-term memory.

\section{Encoding}

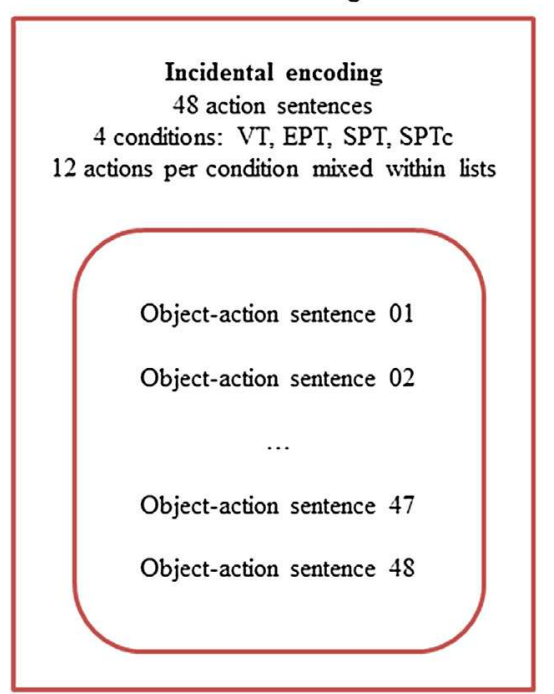

2. Recall

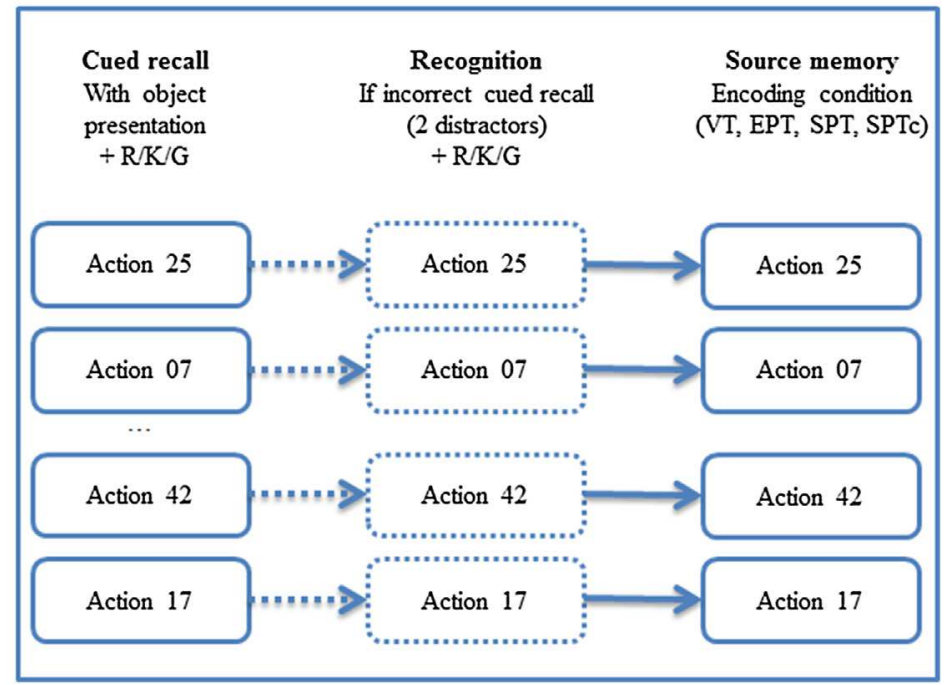

Fig. 1 - General design of the memory for action task. Forty-eight action verbs and 48 objects were used in this task, paired in a semi-random way so as to avoid typical/well-integrated ("write with the pen"), dangerous ("throw the hammer in the air") or impossible ("twist the cell phone") utilisations of each item. We created 20 different lists of 48 object-action sentences, randomly attributed to each participant. Four extra object-action sentences (one for each condition described below) were used for training prior to the task to check that the participants understood the instructions. To ensure incidental encoding, participants were not aware they had to remember either actions or objects. During the encoding phase, an object was placed on a table in front of the participant and a sentence describing the relevant object-action pair was shown on a computer screen for $5 \mathrm{~s}$, using E-Prime software. The design included four encoding conditions (mixed within each list). In the VT condition, participants read aloud the sentence displayed on the computer (no action performed), and in the EPT condition, they watched the experimenter performing the action displayed on the screen. In the SPT condition, however, participants actually performed the action displayed on the computer, and in the SPTc condition, they both chose and performed an action with each item named on the computer screen. We expected the latter condition to enhance the effect, in line with Engelkamp's (2001) theory on action planning. Immediately after the 48 trials, all the objects were brought out again and their names were displayed on the computer, one after the other (in a different random order from that of the encoding phase to avoid an order effect). In this CR phase, participants had to remember the action associated with each object. In the case of a wrong answer, the correct sentence was displayed on the screen, along with two nonstudied distractor sentences, and participants had to select the right one (recognition). Immediately after each correctly recalled or recognized item, we assessed the participants' source memory by asking them to recall the encoding context of each sentence (read: VT; seen: EPT; self-performed: SPT; or self-performed with choice: SPTc). Their scores were expressed as a percentage of the maximum possible score. For each correctly recalled or recognized item (in CR or recognition), we also administered a Remember/Know/Guess (R/K/G) paradigm to assess the participants' subjective experience of the retrieval process (the $\mathrm{R}, \mathrm{K}$ and $\mathrm{G}$ scores for all tasks are expressed as percentages in the statistical analysis). 


\subsection{Anxiety and mood assessments}

State and trait anxiety was assessed by means of the StateTrait Anxiety Inventory (STAI: Spielberger, 1983). Mood state was evaluated by means of the Beck Depression Inventory (BDI; Beck, Rial, \& Rickets, 1974) and the BefindlichkeitsSkala adjective mood scale (Bf-S Von Zerssen, Koeller, \& Rey, 1970).

Total duration for all tests administered was about $3 \mathrm{~h}$.

\subsection{Statistical methodology}

The statistical analysis of the memory for action task scores was carried out using repeated-measures ANOVA, with Group (acute TGA, day-after TGA, healthy controls) as the betweenparticipants factor and Condition (VT, EPT, SPT, SPTc) as the within-participants factor. The remaining data were analysed using a one-way ANOVA, with Group as a betweenparticipants factor. Post hoc Tukey tests were used to carry out paired comparisons.

Pearson correlation coefficients were conducted on the acute TGA group to determine which processes were involved in the enactment effect. To this end, we calculated two improvements by action indices (we deliberately chose not to use the expression enactment effect to avoid confusion between these indices and the differences between the SPT and VT conditions in the memory for action task described above). The classic action improvement index (SPT/VT) was calculated by dividing the total score in the SPT condition by the total score in the VT condition. The chosen action improvement index (SPTc/ VT) was calculated by dividing the total score in the SPTC condition by the total score in the VT condition.

\section{Results}

\subsection{Memory for action task}

For the CR score, we found a main effect of Group, $F(2$, $39)=128.09, p<.0001$, and Condition, $F(3,39)=36.40$, $p<.0001$, but no Group $\times$ Condition interaction, $F(6$, $117)=1.79, p=.11$. Results are set out in Table 3.

Analyses of the total score ( $\mathrm{CR}+$ recognition) showed a main effect of Group, $F(2,39)=30.72, p<.0001$, and Condition, $F(3,39)=20.67, p<.0001$, but no Group $\times$ Condition interaction, $F(6,117)=.85, p=.54$. Results are set out in Table 4 .
In this condition, we observed the classic enactment effect (SPT $>$ VT), as well as the chosen enactment effect (SPTC $>$ VT), both for acute patients and for healthy controls. Post hoc Tukey tests also revealed better performances under the SPTc condition than under the EPT one by the acute patient group. No difference was found between the conditions within the dayafter group.

The acute group performed more poorly than the healthy controls in all four conditions, and more poorly than the dayafter group in the VT and SPT conditions.

Regarding the $\mathrm{R} / \mathrm{K} / \mathrm{G}$ paradigm, we found a main effect of Condition, $F(2,39)=27.46, p<.0001$, a trend towards a Group effect, $F(2,39)=2.96, p=.065$, and a Group $\times$ Condition interaction, $F(4,68)=8.80, p<.0001$. Post hoc Tukey tests showed that patients in the acute phase of TGA gave more $\% \mathrm{G}$ answers than \%R or \% $\mathrm{K}$ answers. We also found that acute patients gave fewer \%K answers and more \%G answers than the healthy controls did.

Concerning the source memory score, we found a significant main effect of Group, $F(2,39)=16.64, p<.0001$, and Condition, $F(3,39)=2.80, p<.05$, but no Group $\times$ Condition interaction, $F(6,117)=.98, p=.45$. Post hoc analyses revealed that healthy controls had better source memory performances in the SPT condition compared with the acute patients, and better performances in the EPT condition compared with the day-after patients. Intragroup comparisons did not reach statistical significance for any of the three groups (see Supplementary material).

\subsection{Complementary cognitive assessment}

The detailed scores for cognitive and anxiety assessments are set out in Table 5 .

As expected, a significant effect of Group was found in ESR for the immediate $C R, F(2,39)=3.78, p<.05$, free recall, $F(2$, $39)=21.96, p<.0001$, and recognition scores $F(2,39)=15.40$, $p<.0001$ (Table 3), with poorer performances for acute patients. The analysis of $\mathrm{R} / \mathrm{K} / \mathrm{G}$ paradigm performances revealed a significant effect of Group on the \%R, $F(2,39)=21.19$, $p<.0001$, and \%G scores, $F(2,39)=787, p=.02$, but not on the $\%$ $\mathrm{K}$ scores, $F(2,39)=13.30, p=.46$, with lower $\% \mathrm{R}$ and higher $\% \mathrm{G}$ scores for acute patients than the other groups.

No statistical difference was found between the three groups in performances on the binding task, Stroop interference test, Part B of the TMT, forward digit span or forward visuospatial span.

Table 3 - CR scores of patients and healthy controls in all memory for action conditions.

\begin{tabular}{|c|c|c|c|}
\hline & Acute TGA $(n=16)$ & Day-after TGA $(n=8)$ & Healthy controls $(n=18)$ \\
\hline VT: number of correct responses (SD) & $.81^{\mathrm{a}, \mathrm{b}}(0,46)$ & $3.75^{\mathrm{a}}(.99)$ & $7.69(.85)$ \\
\hline EPT: number of correct responses (SD) & $.69^{\mathrm{a}, \mathrm{b}}(.35)$ & $5.25^{\mathrm{a}}(1.58)$ & $9.31(.80)$ \\
\hline SPT: number of correct responses (SD) & $1.94^{\mathrm{a}, \mathrm{b}}(1.06)$ & $5.38^{\mathrm{a}}(1.28)$ & $10.46^{\mathrm{C}}(.53)$ \\
\hline SPTc: number of correct responses (SD) & $4.06^{\mathrm{a}, \mathrm{b}, \mathrm{c}, \mathrm{d}, \mathrm{e}}(1.20)$ & $7.38^{\mathrm{a}, \mathrm{c}}(1.00)$ & $11.23^{\mathrm{c}, \mathrm{d}}(.55)$ \\
\hline \multicolumn{4}{|c|}{$\begin{array}{l}\text { a Significant difference from healthy control group in the same condition. } \\
\text { b Significant difference from day-after group in the same condition. } \\
\text { c Significant difference with VT condition within the same group (enactment effect). } \\
\text { d Significant difference with EPT condition within the same group. } \\
\text { e Significant difference with SPT condition within the same group. }\end{array}$} \\
\hline
\end{tabular}




\subsection{Anxiety and mood assessments}

Unlike trait-STAI, we found a significant difference between groups in scores on the state-STAI, F $(2,39)=13.51, p<.0001$, BDI, $F(2,39)=3.36, p<.05$, and Bf-S, $F(2,39)=10.24, p<.001$. Post hoc analyses showed that the acute patients scored more highly on the state-STAI, BDI and Bf-S than the healthy controls.

\subsection{Correlations}

For acute patients, regarding the SPT/VT action improvement index, negative correlations $(p<.05)$ were found with incorrect responses on the binding task $(r=-.73$; i.e., the fewer incorrect responses provided by patients in the binding task, the more their memory was enhanced in the SPT condition) and state anxiety $(r=-.94$; i.e., the less anxious patients were, the more their memory was enhanced in the SPT condition). Moreover, a correlation was found between the SPTc/VT action improvement index and the forward visuospatial span score $(r=.90)$. No other significant correlations were found (see Table 6).

\section{Discussion}

The results of the present study show that, despite their severe episodic memory impairment, TGA patients can still benefit from the enactment effect. This is the first time that this effect has been demonstrated in a sample of patients with such a pure and massive episodic memory deficit. We also highlighted links between the enactment effect and binding. We discuss below the implications of these results at both theoretical and clinical levels.

The first aim of this study was to assess the enactment effect in TGA (i.e., better recall for actions that are actually performed rather for ones that are just verbally encoded). The main finding was that TGA patients in the acute phase can benefit from SPT conditions just as much as healthy controls, even if they still do not perform normally. We labelled this enactment effect (SPT > VT) classic, to distinguish it from the chosen enactment effect (SPTC $>$ VT) discussed below. Our results confirm that this classic enactment effect is present in amnesia, consistent with findings from Korsakoff patients (Mimura et al., 1998), allowing us to conclude that it is not impaired by amnesia per se. In our study, we went one step further, as this is the first time that the enactment effect has been found in a very pure, nonpermanent amnesia without any cognitive reorganization.

In addition to the classic enactment effect (SPT $>$ VT), we observed a chosen enactment effect (SPTC $>$ VT) in the acute patients, even for CR. However, this chosen enactment effect may also have been due to the very high rate of typical actions, which are known to be well-integrated (Mangels \& Heinberg, 2006) and more familiar. Future studies will need to address this issue by distinguishing between typical or well-integrated and poorly integrated actions, as well as the self-reference effect, in the new SPTc condition proposed here. We therefore only discuss the classic enactment effect below, from the perspective of their underlying cognitive functions.

Our second objective was to gain a better understanding of the cognitive functions that sustain memory enhancement in the enactment effect. First, we highlighted a link between a specific binding task and the classic enactment effect (assessed with the SPT/VT action improvement index). This result suggests the involvement of the episodic buffer in the enactment effect and is consistent with the episodic integration view discussed below (Kormi-Nouri \& Nilsson, 1998).

The classic enactment effect (SPT $>$ VT) found in the acute patients and the healthy control group, added to the absence of any significant improvement between the VT and EPT conditions for any of the groups, is consistent with the hypothesis that the enactment effect has a motor component (Engelkamp, 2001), even in the absence of any improvement between the EPT and SPT conditions (Feyereisen, 2009). Regarding glue theory, which assumes that enactment encoding cements actions and objects together (Kormi-Nouri \& Nilsson, 2001), the close correlation found between binding scores and the SPT/VT action improvement index is consistent with the notion that binding plays a role in the enhancement of memory for actions in TGA patients. Thus, we suggest that both the motor control component and episodic integration processes (binding) contribute to the classic enactment effect seen in TGA patients. Our results support the idea of a spared episodic buffer (Quinette, Guillery-Girard, Noël et al., 2006) for the classic enactment effect to occur.

By contrast, spared episodic memory may not be required for enactment effect. In the acute group, we did not observe any link between episodic memory scores and the action improvement indices or improvement in source memory between VT and SPT. We suggest that, instead of stemming from a genuine episodic improvement, the enactment effect is sustained by implicit mechanisms, consistent with massive

Table 4 - Total scores (CR + recognition scores, $C R+R)$ of patients and healthy controls in all memory for action conditions.

\begin{tabular}{lccc}
\hline & Acute TGA $(n=16)$ & Day-after TGA $(n=8)$ & Healthy controls $(n=18)$ \\
\hline VT: number of correct responses (SD) & $4.25^{\mathrm{a}, \mathrm{b}}(.85)$ & $7.88(.68)$ & $8.46(1.01)$ \\
EPT: number of correct responses (SD) & $5.06^{\mathrm{a}, \mathrm{b}}(1.09)$ & $8.63(.46)$ & $9.77(.55)$ \\
SPT: number of correct responses (SD) & $6.75^{\mathrm{a}, \mathrm{c}}(1.50)$ & $9.38(.96)$ & $10.77^{\mathrm{c}}(.51)$ \\
SPTc: number of correct responses (SD) & $7.81^{\mathrm{a}, \mathrm{c}, \mathrm{d}}(1.51)$ & $9.75(.88)$ & $11.31^{\mathrm{c}}(.43)$ \\
\hline a Significant difference from healthy control group in the same condition. & \\
b Significant difference from day-after group in the same condition. & \\
c Significant difference with VT condition within the same group (enactment effect). \\
d Significant difference with EPT condition within the same group. \\
\hline
\end{tabular}


Table 5 - Participants' neuropsychological results expressed as means (SD).

\begin{tabular}{lccc}
\hline & Acute TGA $(n=16)$ & Day-after TGA $(n=8)$ & Healthy controls $(n=18)$ \\
\hline Binding: incorrect answers & $5.20(4.84)$ & $5.13(4.02)$ & $6.36(3.41)$ \\
Stroop interference: time & $133.06(24.73)$ & $135.00(32.01)$ & $122.85(36.96)$ \\
Stroop interference: errors & $2.50(1.93)$ & $2.38(1.51)$ & $3.31(2.87)$ \\
TMT B: time & $105.13(27.14)$ & $117.13(59.08)$ & $93.85(34.30)$ \\
TMT B: errors & $.60(.74)$ & $.75(.89)$ & $.38(.65)$ \\
Forward digit span & $5.06(1.24)$ & $5.71(1.11)$ & $5.46(.77)$ \\
Forward visuospatial span & $5(.63)$ & $5.29(2.92)$ & $5.15(.98)$ \\
ESR CR & $12.94^{\mathrm{a}}(3.19)$ & $14.63(1.30)$ & $15.85(.38)$ \\
ESR free recall & $3.19^{\mathrm{a}, \mathrm{b}}(2.70)$ & $6^{\mathrm{a}}(1.86)$ & $8.85(1.9)$ \\
ESR recognition & $9.56^{\mathrm{a}, \mathrm{b}}(4.77)$ & $14.38(1.30)$ & $15.92(.27)$ \\
ESR \%R & $25.38^{\mathrm{a}, \mathrm{b}}(33.18)$ & $64.66^{\mathrm{a}}(22.87)$ & $71.36(22.45)$ \\
ESR \%K & $34.03(19.23)$ & $23.58(22.92)$ & $23.44(12.74)$ \\
ESR \%G & $40.59^{\mathrm{a}, \mathrm{b}}(45,55)$ & $11.76(13.39)$ & $6.20(3.22)$ \\
Trait-STAI & $43.5(6.23)$ & $39.63(8.73)$ & $37.54(6.64)$ \\
State-STAI & $49.75^{\mathrm{a}}(13.85)$ & $41.50^{\mathrm{a}}(10.74)$ & $28(7.07)$ \\
BDI & $5.69^{\mathrm{a}}(3.91)$ & $4.38(1.85)$ & $2.46(3.23)$ \\
Bf-S adjective mood scale & $28.73^{\mathrm{a}}(10.09)$ & $22.00(7.40)$ & $8.38(7.39)$ \\
\hline a Significant difference from healthy control group. & & \\
b Significant difference from day-after group. & & \\
\hline
\end{tabular}

episodic memory impairment and implicit memory preservation in TGA (Eustache et al., 1997), or by semantic memory (Beauregard et al., 1997; Guillery et al., 2001). Nevertheless Jon, with spared semantic memory (Gardiner et al., 2006), did not benefit from enactment effect for action phrases (without object) recognition. Those results suggest that enactment effect needs episodic buffer, but can occur independently of, or is only sparsely influenced by, episodic memory. The role of semantic memory and implicit mechanisms need to be explored in future researches.

Moreover, we found a negative correlation between the SPT/VT action improvement index and state-anxiety score. This suggests an influence of state-anxiety on enactment effect, with a more important effect for the less anxious patients, although every patient showed better performances for SPT compared to VT. Besides supporting the importance of state-anxiety level on memory performances during TGA

Table 6 - Correlations between action improvement index (SPT/VT), neuropsychological scores, anxiety and mood scales in patients during TGA ( $r$ values).

\begin{tabular}{lcc}
\hline & SPT/VT index & SPTC/VT index \\
\hline Binding: incorrect answers & $-.73^{\mathrm{a}}$ & -.47 \\
Stroop interference: time & -.10 & -.28 \\
Stroop interference: errors & .75 & .20 \\
TMT B: time & .33 & .51 \\
TMT B: errors & -.33 & -.03 \\
Forward digit span & -.25 & -.74 \\
Forward visuospatial span & .30 & $.90^{\mathrm{a}}$ \\
ESR CR & .66 & .01 \\
ESR free recall & .52 & .53 \\
ESR recognition & -.58 & -.26 \\
Trait-STAI & -.30 & -.58 \\
State-STAI & $-.94^{\mathrm{a}}$ & -.77 \\
BDI & .08 & -.65 \\
Bf-S adjective mood scale & .24 & .27 \\
\hline a Significant correlation $p<.05$. & & \\
\hline
\end{tabular}

(Hainselin et al., 2011; Noël et al., 2008), it reinforces the robustness of enactment effect, which can be found even in anxious (and amnesic) patients.

In conclusion, the present experiment demonstrated that the enactment effect is robust enough to be found during a TGA episode. Our newly designed paradigm, featuring an original condition and a source memory assessment, in addition to a neuropsychological assessment, helped us to refine current understanding of the enactment effect. Further studies are now needed to 1) undertake a more in-depth exploration of enactment effect and its links with cognitive and emotional factors, and 2) integrate these very robust effects into clinical practice and rehabilitation, possible even for patients with a massive memory impairment.

\section{Study funding}

This work was supported by Caen University Hospital, as part of a clinical research project. INSERM managed the $\mathrm{PhD}$ funding of Mathieu Hainselin, provided by Lower Normandy Regional Council and the Vicq d'Azyr association.

\section{Conflict of interest}

There is no competing interest.

\section{Acknowledgements}

The authors would like to thank Sandrine Bioux, Evangeline Bliaux, Carole Girard and Sophie Longeray for collecting the data.

We are also grateful to the staff of the Accident and Emergency Department, Neurology Units and Clinical Research Department at Caen University Hospital, and the 
Emergency Neurology Unit at Rouen University Hospital for their unstinting cooperation.

\section{Supplementary data}

Supplementary data related to this article can be found at http://dx.doi.org/10.1016/j.cortex.2013.10.007.

\section{R E F E R E N C E S}

Bartsch, T., Alfke, K., Wolff, S., Rohr, A., Jansen, O., \& Deuschl, G. (2008). Focal MR spectroscopy of hippocampal CA-1 lesions in transient global amnesia. Neurology, 70(13), 1030-1035.

Beauregard, M., Weiner, J., Gold, D., \& Chertkow, H. (1997). Word priming during and after transient global amnesia: A case report. Neurocase, 3, 451-459.

Beck, A. T., Rial, W. Y., \& Rickets, K. (1974). Short form of depression inventory: Cross validation. Psychological Reports, 34(3), 1184-1186.

Engelkamp, J. (1998). Memory for Actions. Hove: Psychology Press.

Engelkamp, J. (2001). Action memory: A system-oriented approach. In H. D. Zimmer, R. L. Cohen, M. J. Guynn, J. Engelkamp, R. Kormi-Nouri, \& M. A. Foley (Eds.), Memory for Action: A Distinct form of Episodic Memory? (pp. 46-96). NewYork: Oxford University.

Eustache, F., Desgranges, B., Petit-Taboue, M., de La Sayette, V., Piot, V., Sable, C., et al. (1997). Transient global amnesia: implicit/explicit memory dissociation and PET assessment of brain perfusion and oxygen metabolism in the acute stage. Journal of Neurology, Neurosurgery \& Psychiatry, 63(3), 357-367.

Feyereisen, P. (2009). Enactment effects and integration processes in younger and older adults' memory for actions. Memory, 17(4), 374-385.

Gardiner, J. M., Brandt, K. R., Vargha-Khadem, F., Baddeley, A., \& Mishkin, M. (2006). Effects of level of processing but not of task enactment on recognition memory in a case of developmental amnesia. Cognitive Neuropsychology, 23(6), 930-948.

Gardiner, J. M., Ramponi, C., \& Richardson-Klavehn, A. (1998). Experiences of remembering, knowing, and guessing. Consciousness and Cognition, 7(1), 1-26.

Godefroy, O. (2008). Fonctions exécutives et pathologies neurologiques et psychiatriques.

Guillery, B., Desgranges, B., Katis, S., de La Sayette, V., Viader, F., \& Eustache, F. (2001). Semantic acquisition without memories: Evidence from transient global amnesia. NeuroReport, 12(17), 3865-3869.

Hainselin, M., Quinette, P., Desgranges, B., Martinaud, O., Hannequin, D., de La Sayette, V., et al. (2011). Can we remember future actions yet forget the last two minutes? Study in transient global amnesia. Journal of Cognitive Neuroscience, 23(12), 4138-4149.

Hainselin, M., Quinette, P., Desgranges, B., Martinaud, O., de La Sayette, V., Hannequin, D., et al. (2012). Awareness of disease state without explicit knowledge of memory failure in transient global amnesia. Cortex, 48(8), 1079-1084.

Hainselin, M., Quinette, P., \& Eustache, F. (2013). What memory for action is? Review and perspectives. Revue de Neuropsychologie, 5(2).

Hodges, J. R., \& Warlow, C. P. (1990). The aetiology of transient global amnesia. A case-control study of 114 cases with prospective follow-up. Brain, 113(3), 639-657.
Kazui, H., \& Tanabe, H. (1995). Hippocampus and memory disturbance: study on cases of transient global amnesia with dysfunction in the medial temporal lobe. No To Shinkei, 47(5), 421-428.

Kormi-Nouri, R., \& Nilsson, L.-G. (1998). The role of integration in recognition failure and action memory. Memory \& Cognition, 26(4), 681-691.

Kormi-Nouri, R., \& Nilsson, L.-G. (2001). The motor component is not crucial! In H. D. Zimmer, R. L. Cohen, M. J. Guynn, J. Engelkamp, R. Kormi-Nouri, \& M. A. Foley (Eds.), Memory for Action: A Distinct form of Episodic Memory? (pp. 97-111) New York: Oxford University.

Madan, C. R., \& Singhal, A. (2012). Using actions to enhance memory: effects of enactment, gestures, and exercise on human memory. Frontiers in Psychology, 3, 507.

Mangels, J. A., \& Heinberg, A. (2006). Improved episodic integration through enactment: implications for aging. The Journal of General Psychology, 133(1), 37-65.

Mimura, M., Komatsu, S., Kato, M., Yashimasu, H. Wakamatsu, N., \& Kashima, H. (1998). Memory for subject performed tasks in patients with Korsakoff syndrome. Cortex, 34(2), 297-303.

Nilsson, L.-G. (2000). Remembering actions and words. In E. Tulving, \& F. I. M. Craik (Eds.), The Oxford Handbook of memory (pp. 137-148). New York: Oxford University Press.

Noël, A., Quinette, P., Guillery-Girard, B., Dayan, J., Piolino, P., Marquis, S., et al. (2008). Psychopathological factors, memory disorders and transient global amnesia. The British Journal of Psychiatry, 193(2), 145-151.

Peigneux, P., \& Van der Linden, M. (2000). Présentation d'une batterie neuropsychologique et cognitive pour l'évaluation de l'apraxie gestuelle. Revue de Neuropsychologie, 10(2), $311-362$.

Quinette, P., Guillery-Girard, B., Dayan, J., de La Sayette, V., Marquis, S., Viader, F., et al. (2006). What does transient global amnesia really mean? Review of the literature and thorough study of 142 cases. Brain, 129(7), 1640-1658.

Quinette, P., Guillery-Girard, B., Hainselin, M., Laisney, M., Desgranges, B., \& Eustache, F. (2013). Évaluation du buffer épisodique: deux épreuves testant les capacités d'association et de stockage d'informations verbales et spatiales. Reuue de Neuropsychologie, 5(1), 56-62.

Quinette, P., Guillery-Girard, B., Noël, A., de La Sayette, V., Viader, F., Desgranges, B., et al. (2006b). The relationship between working memory and episodic memory disorders in transient global amnesia. Neuropsychologia, 44(12), 2508-2519.

Signoret, J. L., Allard, M., Benoit, N., Bolgert, F., Bonvarlet, M., \& Eustache, F. (1989). Evaluation des troubles de mémoire et des désordres cognitifs associés, BEC 96. Paris: IPSEN.

Spielberger, C. D. (1983). Manual for the State-Trait Anxiety. Palo Alto, CA: Consulting Psychologist Press.

Thompson, R. (1959). Learning in rats with extensive neocortical damage. Science, 129(3357), 1223-1224.

Tulving, E. (2002). Episodic memory: From mind to brain. Annual Review of Psychology, 53, 1-25.

Von Zerssen, D., Koeller, D. M., \& Rey, E. R. (1970). A scale for the objective evaluation of the state of subjective well-being as a method for longitudinal studies. Arzneimittel-forschung, 20(7), 915-918.

Wechsler, D. (1991). Echelle clinique de mémoire révisée Paris. Editions. de Psychologie Appliquée.

Zimmer, H. D., Cohen, R. L., Guynn, M. J., Engelkamp, J., KormiNouri, R., \& Foley, M. A. (2001). Memory for Action: A Distinct form of Episodic Memory. New York: Oxford University Press. 